\title{
Bezpieczeństwo europejskie czterdzieści lat po podpisaniu Aktu Końcowego KBWE
}

\section{Znaczenie Aktu Końcowego KBWE}

Kiedy 1 sierpnia 1975 r. podpisywano w Helsinkach Akt Końcowy Konferencji Bezpieczeństwa i Współpracy w Europie, nasz kontynent był podzielony na dwa rywalizujące bloki polityczno-wojskowe, którym przewodziły dwa supermocarstwa ZSRR i Stany Zjednoczone Ameryki. Tylko niektóre państwa cieszyły się względną niezależnością korzystając ze statusu neutralności lub niezaangażowania. Ale nawet na nie nakładał się podział ideologiczny, który sprawiał, że niewidoczna linia odseparowywała Europę Zachodnią od Europy Wschodniej. Mieszkańcy obu części kontynentu byli oddzieleni od siebie żyjąc w odmiennych systemach społeczno-politycznych i mając przeciwstawne wizje przyszłości. Zimna wojna podzieliła nie tylko państwa, ale i społeczeństwa a nawet pojedynczych ludzi. Społeczeństwa europejskie były zakładnikami zmilitaryzowanej rywalizacji międzyblokowej, a za względne poczucie bezpieczeństwa musiały płacić wysoką cenę ograniczeń w kontaktowaniu się ze swoimi sąsiadami zza ,żelaznej kurtyny”. We wschodniej części kontynentu koszty podziału były szczególnie dotkliwe, ze względu na ograniczenia praw i swobód obywatelskich i nieefektywnej gospodarki.

Podpisany, po dwóch latach żmudnych rokowań prowadzonych przez 35 państw europejskich, USA i Kanadę, Akt Końcowy KBWE miał w tym kontekście ogromne znaczenie. Głównie dlatego, że kodyfikował zasady stosunków między ówczesnymi państwami Wschodu i Zachodu oraz europejskimi krajami neutralnymi i niezaangażowanymi, a przypomnijmy, że jego sygnatariuszami było 35 państw, w tym ZSRR i USA. W zawartej w tzw. pierwszym koszyku problemów Deklaracji zasad rzadzacych stosunkami między państwami uczestniczacymi znalazło się siedem zasad zapisanych w Karcie NZ, a następnie rozwiniętych w Deklaracji zasad prawa międzynarodowego (z 24 października 1970 r.) i trzy niemające wówczas takiego statusu zasady: nienaruszalności granic, integralności terytorialnej, respektowania praw człowieka i podstawowych wolności - łącznie z wolnością myśli, sumienia, religii i przekonań. Ten dekalog stworzył normy zachowania się państw uczestników KBWE, które nie tylko stabilizowały sytuację w podzielonej Europie i otwierały szanse rozwijania wzajemnie korzystnej współpracy w różnych dziedzinach, ale wprowadzały nakaz poszanowania przez państwa praw człowieka, co wówczas nie stanowiło norm ius cogens. Były to zasady typowo europejskie, gdyż właśnie w Europie w minionych dwóch wiekach doszło do krwawych wojen o granice; wojny te skutkowały masowymi naruszeniami praw człowieka, a idea ich ochrony miała genezę europejską w myśli francuskiego Oświece- 
nia i Wielkiej Rewolucji Francuskiej. Nie bez znaczenia było i to, że niedawne europejskie mocarstwa kolonialne miały ciemną kartę w gwałceniu praw narodów podbitych i skolonizowanych. Zapisane w Akcie Końcowym zarówno zasady stosunków między uczestniczącymi państwami, jak i zalecenia w stosunku do współpracy ogólnoeuropejskiej, były rezultatem korzystnego kompromisu. Kreśliły dynamiczną wizję dochodzenia do bezpiecznej Europy, przyjmując za punkt wyjścia istniejący stan rzeczy (Bierzanek, 1980, s. 291-293).

Szczegółowe postanowienia Aktu Końcowego wytyczały również możliwości współpracy gospodarczej, naukowo-technicznej i w zakresie ochrony środowiska (tzw. drugi koszyk problemów) oraz, co szczególnie istotne, w zakresie kultury, oświaty, wymiany informacji i kontaktów międzyludzkich (tzw. trzeci koszyk, konkretyzujący zasadę respektowania praw człowieka). Akt Końcowy KBWE zarazem, więc otwierał szansę na pokojową i demokratyczną transformację autorytarnie rządzonych państw realnego socjalizmu w Europie Środkowej i Wschodniej. Akt helsiński wprowadzał zasadę konsensusu, jako normę wypracowywania wspólnych decyzji. Nikogo nie dyskryminował, a równocześnie wręcz zmuszał państwa do negocjowania tak długo, aż mogły one suwerennie zgodzić się na wspólne decyzje.

Dokument ten okazał się więc niewątpliwym sukcesem, gdyż dostarczył użytecznych instrumentów poszukiwania nowych form i rozwiązań w celu umacniania bezpieczeństwa i rozwijania współpracy między prawie wszystkimi państwami europejskimi (z wyjątkiem niebiorącej wtedy udziału w KBWE Albanii i tzw. państw karłowatych) oraz USA i Kanady. Zarazem otworzył szanse na pokojowa, demokratyczną transformację państw wschodniej części kontynentu, gdyż dał ugrupowaniom opozycyjnym w państwach bloku wschodniego wygodne narzędzie umożliwiające im powoływanie się na normy KBWE, pod którymi podpisały się komunistyczne rządy.

Stworzony w $1975 \mathrm{r}$. w Helsinkach mechanizm paneuropejski sprawdził się w praktyce. Zbierał on przy jednym stole rokowań prawie wszystkie państwa europejskie (z wyjątkiem komunistycznej Albanii i tzw. państw karłowatych). W rokowaniach tych na zasadzie suwerennej równości brały udział państwa obu bloków, Wschodu i Zachodu oraz kraje neutralne i niezaangażowane (tzw. grupa $\mathrm{N}+\mathrm{N}$ ). Pomimo, iż w praktyce przeważał jednak mechanizm blokowy, stanowiło to nową wartość, gdyż dotychczas liderzy obu bloków, ZSRR i Stany Zjednoczone bardzo dbali, aby najważniejsze negocjacje międzynarodowe miały charakter międzyblokowy, gdyż dawało to im możliwość kontrolowania rozwoju sytuacji. Dopuszczenie do KBWE grupy $\mathrm{N}+\mathrm{N}$ zmieniało arytmetykę rokowań, a państwa neutralne i niezaangażowane były żywotnie zainteresowane w doprowadzaniu do konkretnych uzgodnień. Wzrosła rola takich państw pozostających poza blokami jak: Finlandia, Jugosławia, Hiszpania, Szwecja czy Szwajcaria. Proces KBWE choć bardziej formalnie, niż w praktyce, torował drogę do demokratycznych uzgodnień między suwerennymi państwami.

Akt Końcowy KBWE zakładał równoczesne umacnianie bezpieczeństwa wszystkich jego sygnatariuszy. Nie dopuszczal - dzięki zasadzie konsensusu - do podejmowania decyzji korzystnych tylko dla pewnej grupy państw. Wszyscy sygnatariusze godzili się, aby suwerennie i wspólnie wypracowywać nowe rozwiązania gwarantujące im równe bezpieczeństwo i równe korzyści ze wspólpracy. Inną istotną cechą KBWE była metoda dochodzenia do uzgodnień w sprawach bezpieczeństwa przez dialog 
i współpracę polityczną. Właśnie współpracę uznano za główny czynnik budowania bezpieczeństwa, a sposób ksztaltowania bezpieczeństwa w Europie, ze względu na przyjętą metodę, nazwano bezpieczeństwem kooperatywnym.

Proces paneuropejski zapoczątkowany konferencją w Helsinkach rozwijał się w bardzo niesprzyjających warunkach międzynarodowych. Istniały bowiem dwa rywalizujące ze sobą bloki polityczno-wojskowe i często w wyniku ideologizacji oraz militaryzacji polityki zagranicznej ich liderów (ZSRR i USA) dochodziło do niebezpiecznego zaostrzania się napięć międzynarodowych, prowadzących do kryzysów. Takie załamanie się odprężenia między Wschodem a Zachodem miało miejsce w latach 1979-1983. Mimo tego mechanizm negocjacyjny KBWE sprawdził się jako instrument dyplomacji na rzecz odprężenia i budowania zaufania między państwami (Ghebali, 1989). Dowiódł tego sukces Spotkania Madryckiego w trudnych latach 1980-1983, na którym państwa uczestniczące postanowiły rozciagnąć proces KBWE na płaszczyznę wojskową (Rotfeld, 1986).

Na kolejnym Spotkaniu Wiedeńskim, które odbywało sięjuż w korzystnej atmosferze powrotu odprężenia między Wschodem a Zachodem w latach 1986-1989, uzgodniono nowe formy współpracy humanitarnej i w zakresie respektowania praw człowieka. Problematyka praw człowieka i spraw humanitarnych została uznana przez wszystkie państwa uczestniczące za kluczowy problem na drodze umacniania zabezpieczeń międzynarodowego pokoju i bezpieczeństwa w Europie. Ten tzw. ludzki wymiar KBWE sprzyjał promocji przemian demokratycznych, do których przesłanki dojrzewały już w krajach Europy Środkowej i Wschodniej (Heraclides, 1993, s. 174). W Wiedniu podjęto także decyzję zobowiązującą państwa uczestniczące do dostosowania ich prawa wewnętrznego, orzecznictwa i działań politycznych do ich zobowiązań prawnomiędzynarodowych i uchwał KBWE; wprowadzono zapisy wzmacniające respektowanie zasady powstrzymywania się od użycia siły lub groźby jej użycia, a także określono mandat i zasady przygotowywanych rokowań 23 państw w sprawie redukcji zbrojeń konwencjonalnych i 35 państw na temat nowych środków budowy zaufania i bezpieczeństwa w Europie (Lehne, 1991).

Spotkanie Wiedeńskie zakończyło trwający od podpisania Aktu Końcowego KBWE etap weryfikacji i poszerzania procesu helsińskiego. Przygotowało tym samym dogodną podstawę do przejścia do następnego jego etapu, czyli do tworzenia organów KBWE.

\section{Zmieniająca się przydatność KBWE/OBWE po zimnej wojnie}

Po Jesieni Ludów 1989 r. sądzono, że kiedy załamał się ustrój realnego socjalizmu w krajach Europy Środkowej i ZSRR, a niebawem potem rozpadł się blok wschodni i ZSRR, nadeszła era zgodnej współpracy państw wszystkich państw uczestniczących bez podziału na trzy grupy: Zachodu, Wschodu i $\mathrm{N}+\mathrm{N}$. Na paryskim spotkaniu na szczycie w listopadzie 1990 r. rozpoczęto instytucjonalizację strukturalną KBWE. Do procesu włączyły się państwa niebiorące dotychczas udziału lub powstałe po rozpadzie ZSRR. Na spotkaniu na szczycie Helsinki II, w lipcu 1992 r. zadekretowano, że KBWE będzie organizacją regionalną w rozumieniu rozdziału VIII Karty NZ. Jednak w praktyce nie stała się główną instytucją bezpieczeństwa europejskiego. 
Nowe demokratyczne rządy wielu państw tego regionu wybrały kurs na akces do zachodnich struktur bezpieczeństwa (NATO) i integracji (UE). Tmczasem KBWE przemianowana, na podstawie decyzji szczytu w Budapeszcie z grudnia 1994 r., z początkiem następnego, 1995 roku na Organizację Bezpieczeństwa i Współpracy w Europie (OBWE) systematycznie słabła. Wprawdzie w trakcie prowadzonych wówczas prac nad tzw. modelem bezpieczeństwa europejskiego w XXI wieku, jeszcze na szczycie w Lizbonie w grudniu 1996 r., określono OBWE mianem „centralnej” instytucji bezpieczeństwa europejskiego, ale na pierwszy plan wysunęło się NATO, preferowane przez kraje środkowoeuropejskie, w tym przez Polskę. Nie można więc zbyt ostro stawiać sprawy, że OBWE, poniosła już wtedy porażkę. Po prostu większość państw w niej uczestniczących postawiła na inną strukturę międzynarodową. OBWE straciła swoją dotychczasową użyteczność. Natomiast Moskwa, która w pierwszej połowie lat 90. domagała się wzmocnienia KBWE (Kozyriev, 1994) i starała się nie dopuścić do rozszerzenia NATO na Wschód, przegrała tę batalię dyplomatyczną, a kolejne rozszerzenia NATO oceniała jako realizowanie - głównie przez USA - mocarstwowej polityki „podchodzenia” do granic Rosji. W tym kontekście należy także oceniać niedawne zachowanie Rosji w kryzysie ukraińskim (który wybuchł w listopadzie 2013 r.), w tym jej decyzję z 2014 r. o złamaniu prawa międzynarodowego i norm KBWE w formie aneksji Krymu i wspierania separatyzmu wschodnich obwodów Ukrainy. Moskwie zależy przede wszystkim, aby nie dopuścić do „wciagnięcia” przez Zachód Ukrainy do swojej strefy wpływów (Zięba, 2014, s. 23-26). Opinia ta nie oznacza jednak, że należy całkowicie zdezawuować OBWE jako instytucję bezpieczeństwa międzynarodowego.

Główną funkcją KBWE/OBWE po zimnej wojnie stało się stabilizowanie ładu pokojowego w strefie „od Vancouver po Władywostok”, a to zostało oparte na wizji wszechstronnego i kooperatywnego bezpieczeństwa niepodzielonej, demokratycznej, współpracującej i otwartej na świat Europy, z udziałem USA i Kanady. Wyraźnie to podkreślono w Paryskiej Karcie Nowej Europy, przyjętej w listopadzie 1990 r. Nawet już poczynając od lat 70. mechanizm KBWE miał służyć wytyczaniu kierunku przemian w Europie, co rozumiano jako podnoszenie standardu norm i zachowań międzynarodowych oraz upowszechnianie wartości demokratycznych. Na początku lat 90 . dopisano do jej zadań wczesne ostrzeganie, dyplomację prewencyjną i rozwiązywanie kryzysów oraz stabilizowanie ładu wojskowego (poprzez kolejne generacje środków budowania zaufania i bezpieczeństwa oraz układy o ograniczeniu zbrojeń konwencjonalnych w Europie). Zasadnicze znaczenie miały tutaj decyzje szczytu KBWE w Helsinkach w 1992 r. oraz układy CFE I z 1992 r. i CFE II z 1999 r. (Zięba, 2004, s. 299 i n.).

KBWE/OBWE została skonstruowana jako organizacja o bardzo szerokim spektrum działania. Jednak w praktyce państwa członkowskie nie wyposażyły jej w adekwatne do stawianych zadań zasoby i instrumenty działania. Najszerzej zostały rozbudowane jej wymiary polityczny i ludzki (humanitarny), słabiej wymiar ekonomiczny i ekologiczny oraz wojskowy. W rezultacie OBWE dysponuje tzw. miękkimi środkami umacniania bezpieczeństwa, a nie posiada tzw. twardych instrumentów, np. w postaci sił pokojowych do prowadzenia operacji rozwiązywania kryzysów.

Można zatem postawić pytanie: jakie zadania ma OBWE obecnie? Z pewnością można stwierdzić, że OBWE koncentruje się na dialogu międzynarodowym, a stanowi drugie po ONZ najszersze forum złożone obecnie z 57 państw, deliberuje na tematy 
praw człowieka i upowszechniania wartości demokratycznych, zaś jej tzw. misje w terenie mają charakter obserwacyjny i mediacyjny. Operacje wojskowe i policyjne na obszarze OBWE wykonują ONZ, UE i NATO. Tak więc same państwa członkowskie OBWE zdecydowały, że ich organizacja nie może pełnić zapowiadanej w latach 90 . roli centralnej instytucji bezpieczeństwa europejskiego. W rezultacie w przyjętym w listopadzie 1999 r. na szczycie w Stambule dokumencie pn. Karta Bezpieczeństwa Europejskiego nie powtórzono określenia z Lizbony o „centralnym” charakterze tej organizacji. Uzgodniono formułę, że OBWE jest „pierwszorzędną organizacją do celów pokojowego rozwiązywania sporów w regionie i kluczowym instrumentem w zakresie wczesnego ostrzegania, zapobiegania konfliktom, rozwiązywania kryzysów i rehabilitacji po konfliktach” oraz „wyspecjalizowana, całościową konsultacyjną organizacją podejmowania decyzji i współpracy w regionie euroatlantyckim". W załączonej „Platformie bezpieczeństwa kooperatywnego" zapowiedziano, że OBWE będzie współpracować z innymi organizacjami i instytucjami bezpieczeństwa w strefie euroatlantyckiej, odgrywając ,"pełną i odpowiednią rolę w rozwoju stosunków między wzajemnie wzmacniającymi się instytucjami bezpieczeństwa w strefie OBWE" (Charter for European Security, 1999). W praktyce jednak OBWE stała się drugorzędną organizacją zajmującą się „,miękkimi” aspektami bezpieczeństwa w strefie euroatlantyckiej.

\section{Odchodzenie od zasady równego bezpieczeństwa w Europie}

Dalszy rozwój sytuacji w Europie, a zwłaszcza rozszerzenie NATO (1999, 2004, 2009) i Unii Europejskiej $(2004,2007,2013)$ przesądziły w następnych latach, że OBWE nie była w stanie realnie kształtować bezpieczeństwa w strefie euroatlantyckiej. Głównymi graczami okazały się USA, UE oraz Rosja odbudowująca swoją pozycję międzynarodową po okresie „smuty" w latach przywództwa Borysa Jelcyna. Poczynając od początku XXI wieku Rosja rządzona przez Władimira Putina staje się państwem coraz silniejszym, a w lutym 2007 r. na monachijskiej konferencji bezpieczeństwa prezydent Putin upomniał się o „należne” Rosji miejsce jednego z głównych graczy w ładzie światowym. Po zapowiedzi szczytu NATO w Bukareszcie z kwietnia 2008 r., że Ukraina i Gruzja staną się członkami Sojuszu, Rosja przeszła do zdecydowanych działań mających temu zapobiec. Po sierpniowym ataku Gruzji na wojska rosyjskie stacjonujące jako siły pokojowe na terenie Osetii Południowej (leżącej na terytorium Gruzji), Rosja dokonała nieproporcjonalnej odpowiedzi militarnej. OBWE nie była w stanie nic zrobić dla zażegnania kryzysu, a misję mediacyjną przeprowadziła Francja, a potem UE.

Podobnie było z rolą OBWE w kryzysie ukraińskim, przynajmniej w jego pierwszej fazie. Kryzys ten ma swoje głębokie przyczyny w sytuacji wewnętrznej na Ukrainie i braku determinacji ówczesnych władz tego państwa (prezydenta Wiktora Janukowycza) w sprawie podpisania nowej umowy o stowarzyszeniu i pogłębionej strefie wolnego handlu między Ukrainą a UE. Jednak wsparcie udzielone przez USA i UE nowym prozachodnim władzom w Kijowie, wyłonionym w lutym 2014 r. w wyniku demonstracji ulicznych, zostało wykorzystane przez Rosję po to, aby nie dopuścić do związania się Ukrainy z Zachodem. Rosja przeszła do otwartych działań mających zatrzymać 
Ukrainę w orbicie swoich wpływów. Wspomniana wyżej aneksja Krymu i militarne wsparcie secesji Donbasu, jak również samo zakwestionowanie prawa Ukrainy do afiliacji z UE, stanowily oczywiste naruszenie norm KBWE/OBWE, doprowadzily do przypominającej czasy zimnej wojny konfrontacji Rosji z Zachodem. Potwierdzeniem tego są sankcje wobec Rosji, wyłączenie z G8, czy decyzje szczytu NATO w Newport (z września 2014 r.) o militarnym wzmocnieniu wschodniej flanki Sojuszu.

Na pytanie, czy OBWE była w stanie zapobiec temu powrotowi atmosfery zimnowojennej, należy odpowiedzieć raczej negatywnie. A to dlatego, że przyczyny sporu Zachodu z Rosją o Ukrainę mają swoje głębokie źródła, tkwiące w całym rozwoju relacji między Zachodem a Rosja po zimnej wojnie. Zachód, a zwłaszcza USA, nie potrafi partnersko traktować stającej się coraz większym dla nich konkurentem Rosji. Z kolei Rosja nie umie pogodzić się z tym, że Ukraina jest odrębnym i niepodległym państwem. Zaś sytuacji nie ułatwiają sami Ukraińcy, którzy są podzieleni jako społeczeństwo w sprawie wyboru własnej opcji geopolitycznej. Te okoliczności utrudniaja OBWE doprowadzenie do rozwiązania kryzysu ukraińskiego. Nie znaczy to jednak, że uniemożliwiają. Warto odnotować, że OBWE jest jak dotąd jedyną instytucją międzynarodową potrafiącą mediować w tym kryzysie, ma swój udział w doprowadzeniu do porozumienia rozejmowego we wrześniu 2014 r. (tzw. układ Mińsk I).

\section{Stopniowy spadek znaczenia OBWE w polskiej polityce bezpieczeństwa}

W roku 40-lecia od podpisania Aktu Końcowego KBWE Polska ma szczególny tytuł do tego, aby podkreślać znaczenie dzisiejszej OBWE. Pozostając w okowach zimnej wojny w $1964 \mathrm{r}$. wystapiła z inicjatywą zwołania konferencji paneuropejskiej z udziałem USA. Zaproponowała, aby konferencja taka zajęła się całokształtem spraw składających się na bezpieczeństwo i współpracę w Europie. Politycy PRL potrafili wychylić się poza obowiązujące w bloku wschodnim kanony i odważnie proponowali włączenie do tych debat kwestii współpracy w dziedzinach „wrażliwych”, takich jak kultura, oświata, wymiana informacji i kontakty międzyludzkie. Jako rzecz oczywista uznali udział w takiej konferencji Stanów Zjednoczonych, a także państw neutralnych i niezaangażowanych. Uznali, że najważniejsze są polityczne negocjacje, które będą zbliżać państwa w nich uczestniczące, a szeroka paleta spraw do omawiania pozwoli znaleźć im płaszczyzny porozumienia. Wyciągając wnioski z niepowodzeń swoich wcześniejszych planów stworzenia w Europie Środkowej strefy bezatomowej (Plan Rapackiego) lub zamrożonych zbrojeń jądrowych (plan Gomułki) porzucono idee częściowych kroków rozbrojeniowych na styku dwóch bloków (NATO i Układu Warszawskiego), a skoncentrowano się na lansowaniu szerokich wielostronnych negocjacji prowadzących do całościowego uregulowania problematyki bezpieczeństwa europejskiego i wspomaganiu tego poprzez rozwijanie współpracy w innych dziedzinach (Rachwald, 1983, s. 24).

Ponadto całościowe uregulowanie problemu bezpieczeństwa europejskiego widziano w Warszawie nie jako akt jednorazowy, obejmujący zawarcie układu o bezpieczeństwie zbiorowym, jak to proponował w poprzedniej dekadzie ZSRR, lecz jako proces długofalowych rokowań i zbliżenia między państwami, funkcjonalnej współpracy, 
ksztaltującej wzrost poczucia i poprawę stanu bezpieczeństwa na kontynencie. Nie wykluczano też, że kiedyś może dojść do zawarcia umowy międzynarodowej i stworzenia regionalnej organizacji bezpieczeństwa $\mathrm{z}$ rozwiniętym mechanizmem prawnym (Zięba, Zając, s. 226-227).

Podejście to okazało się słuszne. Nowa propozycja Polski przyczyniła się do zintensyfikowania dialogu międzynarodowego. Odtąd problem umacniania bezpieczeństwa w Europie zaczęto traktować nie tylko jako pożądany cel polityczny, lecz przez pryzmat wskazanej przez Polskę drogi jego osiągania - poprzez rokowania zainteresowanych państw. Idea zwołania konferencji ogólnoeuropejskiej stała się ważnym celem polityki zagranicznej PRL. Była też przedmiotem szeregu dwu- $i$ wielostronnych konsultacji z państwami Wschodu i Zachodu (Bromke, 1983, s. 50). Kontakty oraz konsultacje między państwami Wschodu i Zachodu ułatwiły odchodzenie od zdeformowanego w okresie zimnej wojny myślenia w krajach europejskich o bezpieczeństwie, preferującego własne bezpieczeństwo narodowe (i blokowe), rozumiane przede wszystkim w kategoriach wojskowych - przed lub kosztem bezpieczeństwa innych państw kontynentu. Pod wpływem polskiej inicjatywy (wspartej przez inne państwa Układu Warszawskiego), zaczęło upowszechniać się myślenie i działanie uznające współzależność wymogów bezpieczeństwa państw europejskich.

Głównym motywem skłaniającym władze PRL do zaangażowania się na rzecz KBWE było dążenie do ustabilizowania istniejącego w Europie status quo, którego zasadniczy element stanowiło uzyskanie politycznej akceptacji istniejących granic, w tym granicy na Odrze i Nysie Łużyckiej, przez wszystkie państwa europejskie oraz USA i Kanadę. Dzisiaj uznaje się to, podobnie jak i inne aspekty uczestnictwa PRL w procesie KBWE, za korzystne dla obiektywnego interesu Polski.

Warszawa zmierzała także do łagodzenia - na miarę ówczesnych ograniczonych możliwości - politycznego podziału Europy, który podtrzymywał konfrontację mogącą zagrozić bezpieczeństwu międzynarodowemu, w tym w pierwszej kolejności bezpieczeństwu Polski, położonej w pobliżu linii styku dwóch przeciwstawnych sobie bloków. W ówczesnych elitach politycznych Warszawy istniało głębokie przekonanie, wypowiadane jeszcze w latach 1945-1946 przez Władysława Gomułkę i Zygmunta Modzelewskiego, o tym, że podział Europy sprzyjać będzie podtrzymywaniu antypolskiego rewizjonizmu i rewanżyzmu w Niemczech Zachodnich. W latach 70., kiedy ekipa Edwarda Gierka podjęła politykę modernizacji kraju, w Polsce wzrastało parcie społeczne w kierunku większego otwarcia na Zachód. To przede wszystkim dlatego Warszawa aktywnie angażowała się w promowanie w procesie KBWE współpracy w dziedzinach humanitarnych. Pamiętać bowiem trzeba, że Polska była najbardziej liberalnie rządzonym i otwartym na świat państwem bloku wschodniego.

Faktem jest, że owo otwarcie było kontrolowane przez kierownictwo PZPR, zwłaszcza gdy mogło to prowadzić do osłabiania monopolu jej rządów i utraty zaufania ze strony Moskwy. Jednak to właśnie w Polsce od 1977 r. jako w pierwszym kraju rządzonym przez partię marksistowsko-leninowską tolerowano opozycję demokratyczna, działał Komitet Helsiński monitorujący realizację humanitarnych postanowień Aktu Końcowego KBWE przez władze państwowe. Dochodziło tu także do częstych kryzysów społeczno-politycznych w trakcie, których umacniała się opozycja antysystemowa. W 1980 r. NSZZ "Solidarność” i liberalne skrzydło PZPR podjęły próbę 
wprowadzenia w życie w Polsce, jako pierwszym kraju realnego socjalizmu, idei społeczeństwa obywatelskiego i ustroju demokratycznego zawartą w uchwałach KBWE.

Proces KBWE, zwłaszcza w rezultacie uzgodnień poczynionych w Dokumencie Końcowym Spotkania Wiedeńskiego ze stycznia 1989 r., ustanawiających jednakowe, minimalne standardy w zakresie respektowania praw człowieka $\mathrm{i}$ wyodrębniających „ludzki wymiar” KBWE, wyraźnie sprzyjał promocji przemian demokratycznych, których przesłanki dojrzewały już w krajach Europy Środkowej i Wschodniej. Warto zauważyć, że prace redakcyjne nad sformułowaniem tego dokumentu toczyły się w czasie, gdy w Polsce prowadzono przygotowania do obrad „okragłego stołu” przedstawicieli strony partyjno-rządowej i opozycji.

Nowe nieblokowe myślenie o sprawach bezpieczeństwa europejskiego mogło się szeroko umocnić po przełomie politycznym 1989 r. Pierwszy niekomunistyczny premier Tadeusz Mazowiecki zaproponował w $1990 \mathrm{r}$. utworzenie z siedzibą w Warszawie Rady Współpracy Europejskiej jako głównego organu KBWE. Nie udało się to wówczas, ale przekonaliśmy (na szczycie paryskim KBWE w listopadzie 1990 r.) inne państwa $\mathrm{w}$ sprawie umiejscowienia w Warszawie Biura Wolnych Wyborów, przekształconego w 1992 r. w Biuro Instytucji Demokratycznych i Praw Człowieka (ODIHR), które niebawem stało się głównym organem ludzkiego wymiaru KBWE.

Polska proponowała kolejne środki budowy zaufania i bezpieczeństwa oraz rokowania w sprawie rozbrojenia konwencjonalnego w Europie. Także z naszej inicjatywy szczyt budapeszteński w 1994 r. uchwalił Kodeks postępowania w dziedzinie polityczno-wojskowych aspektów bezpieczeństwa. Nasi dyplomaci często brali udział w misjach terenowych KBWE/OBWE, a w latach 1997-1999 Polska uczestniczyła w tzw. trójce kierowniczej OBWE, a w 1998 r. przewodniczyła całej organizacji. Natomiast Polska nie popierała propozycji wzmacniania OBWE, zgłoszonych przez Rosję i aprobowanych przez niektóre państwa zachodnie, takie jak Francja, Szwajcaria, Niemcy i Holandia, a dyskutowanych w latach 1995-1999, w ramach prac nad modelem bezpieczeństwa europejskiego w XXI wieku. Wynikało to z obawy, aby przez nadanie statusu prawnego OBWE nie doprowadzić do przyznania jej nadrzędnej roli wobec zachodnich struktur bezpieczeństwa, o przyjęcie do których Polska właśnie się ubiegała.

W drugiej połowie lat 90 . wyraźnie widać było jak spadło znaczenie OBWE w polskiej polityce zagranicznej. Główne zainteresowanie polskiej dyplomacji koncentrowało się na zabiegach o podpisanie układu o przystapieniu do Sojuszu Północnoatlantyckiego, potem wspierania procesu ratyfikacji przez państwa NATO tego protokołu, a na drugim miejscu postawiono przygotowania do prowadzenia negocjacji $\mathrm{w}$ sprawie przyjęcia Polski do Unii Europejskiej. Występując w Sejmie 5 marca 1998 r., minister spraw zagranicznych Bronisław Geremek przedstawił takie właśnie priorytety w roku 1998 dla polskiej polityki zagranicznej, a sprawę przewodnictwa Polski w OBWE wymienił dopiero na szóstym miejscu i szerzej jej nie rozwinął. Polska - pomimo przewodniczenia organizacji - nie zorganizowała u siebie posiedzenia Rady Ministerialnej OBWE. Odbyło się ono w grudniu $1998 \mathrm{r}$. w Oslo, a nie w Warszawie.

Generalnie, wysoka była aktywność Warszawy w KBWE/OBWE do czasu przystapienia do NATO w 1999 r. Od tego momentu zainteresowanie Warszawy OBWE znacznie osłabło. Kolejne rządy nie podejmowały realnych zabiegów, aby korzystać z mechanizmu bezpieczeństwa OBWE, ani tym bardziej wzmacniać tej organizacji. 
Jedną z głównych przyczyn osłabienia OBWE były próby wykorzystania jej do promowania demokracji we wschodniej części Europy, w tym w ramach wspieranych - przez państwa NATO i Unii Europejskiej, w tym aktywnie przez Polskę - tzw. kolorowych rewolucji. Polityka owego eksportu demokracji była szczególnie aktywnie prowadzona przez rządzącą w Polsce w latach 2005-2007 partię Prawo i Sprawiedliwość) oraz prezydenta Lecha Kaczyńskiego. Ponieważ w łonie OBWE nie było przyzwolenia na taką politykę promowania demokracji, w tym przy wykorzystaniu warszawskiego Biura Instytucji Demokratycznych i Praw Człowieka, Polska zrezygnowała z korzystania $\mathrm{z}$ tej organizacji jako forum uprawiania własnej polityki (Zięba, 2013, s. 280). W exposé ministra spraw zagranicznych Stefana Mellera w Sejmie 15 lutego $2006 \mathrm{r}$. nie pojawiła się samodzielnie nazwa OBWE.

Potem po przejęciu rządu przez Platformę Obywatelską i Polskie Stronnictwo Ludowe (w listopadzie 2007 r.) nowy premier Donald Tusk w swoim exposé nie wymienił OBWE w żadnym kontekście. Pojawiały się jednak puste deklaracje ministra spraw zagranicznych Radosława Sikorskiego i fasadowe działania, jak np. uczestnictwo w zainicjowanym w czerwcu 2009 r. ,procesie z Korfu”, czyli w dialogu na temat bezpieczeństwa europejskiego, zaproponowanego rok wcześniej przez prezydenta Rosji Dmitrija Miedwiediewa, w sprawie rekonstrukcji „europejskiej architektury bezpieczeństwa" (Grudziński, Pietrusiewicz, 2001, s. 54-55). Polska jako kraj niechętny tej rosyjskiej inicjatywie opowiedziała się za skierowaniem jej na forum OBWE. Uważała, że w centrum uwagi powinno pozostać wzmocnienie OBWE przede wszystkim w dziedzinie zapobiegania i rozwiązywania konfliktów, poprzez m.in. niezbędną modyfikację istniejących i - tam, gdzie to okaże się potrzebne - stworzenie nowych mechanizmów oraz utrzymanie roli Organizacji jako forum konsultacji w sprawach bezpieczeństwa europejskiego. Prezydent Bronisław Komorowski nie wziął udziału w szczycie OBWE w Astanie w grudniu $2010 \mathrm{r}$.

Trzeba jednak przyznać, że Polska przystapiła, razem z Francja, Niemcami i Rosja, do Inicjatywy w sprawie Rozwoju Euroatlantyckiej i Eurazjatyckiej Wspólnoty Bezpieczeństwa (Initiative for the Development of a Euro-Atlantic and Eurasian Security Community - IDEAS), nawiązującej do idei wspólnoty bezpieczeństwa, przyjętej w Deklaracji Szczytu OBWE w Astanie. W 2012 r. instytuty eksperckie z Francji, Niemiec, Rosji i Polski zorganizowały cykl czterech seminariów (w Berlinie, Warszawie, Paryżu i Moskwie) na temat „,Towards a Euro-Atlantic and Eurasian Security Community". Ich rezultatem jest wspólny dokument Towards a Euro-Atlantic and Eurasian Security Community: From Vision to Reality. Został on zaprezentowany przez cztery instytuty na nieformalnym spotkaniu ambasadorów państw członkowskich OBWE 23 października 2012 r. w Wiedniu.

Wypracowany przez analityków z czterech krajów dokument stanowi nowe spojrzenie na wyzwania stojące na drodze umacniania bezpieczeństwa euroatlantyckiego i eurazjatyckiego. Opowiada się za powiązaniem całego obszaru OBWE w jedną całość. Jest to opinia nie rządów, a jedynie ekspertów. Nie jest znany oficjalny stosunek polskiego MSZ do przyjętego raportu, wiele wskazuje bowiem, że Polska dalej nie docenia znaczenia tej organizacji i nie potrafi wyjść poza wąskie grupowe oraz w gruncie rzeczy zmilitaryzowane pojmowanie bezpieczeństwa i w rzeczywistości przyjąć jego całościowe i szerokie rozumienie. 
Generalnie można stwierdzić, że po przystapieniu Polski do NATO i Unii Europejskiej, zdaniem kolejnych rządów, OBWE straciła na znaczeniu i nie jest traktowana jako skuteczna i użyteczna platforma promowania polskich interesów na arenie międzynarodowej. Pomimo, że od czasu do czasu są powtarzane deklaracje ministrów spraw zagranicznych o znaczeniu tej organizacji i potrzebie wydobycia jej z kryzysu, to jednak Warszawa świadomie zrezygnowała z traktowania OBWE jako potrzebnej instytucji zacieśniania współpracy i umacniania bezpieczeństwa w strefie euroatlantyckiej. Taki wybór polityczny stanowi odejście od kursu realizowanego w nieodległej przeszłości, nawet w pierwszych latach po zimnej wojnie. Oznacza to zarazem zrezygnowanie z szerokiego całościowego podejścia do ksztaltowania bezpieczeństwa międzynarodowego, uwzględniającego tzw. miękkie aspekty bezpieczeństwa. Tego wyboru, dokonanego przez Polskę i jej sojuszników, nie można uznać za racjonalny w świetle ciągle pojawiających się nowych wyzwań i zagrożeń bezpieczeństwa o charakterze nietradycyjnym i niemilitarnym. Realia w strefie euroatlantyckiej powinny zdecydowanie skłaniać do preferowania rozwiązań szerokich i opartych na dialogu międzynarodowym, a OBWE jest najszerszą instytucją gromadzącą przy jednym stole 57 państw całej strefy od Vancouver do Władywostoku. To właśnie parafrazując ideę książki znanego amerykańskiego politologa powinno nas uczyć, jak czynić wrogów przyjaciółmi i budować trwały pokój (Kupchan, 2010). OBWE - jak wskazują eksperci zaangażowani w projekt IDEAS - ma szansę stworzyć szeroką euroatlantycką i eurazjatycką wspólnotę bezpieczeństwa.

Nasi politycy postawili na ,twarde” gwarancje bezpieczeństwa stwarzane przez Sojusz Północnoatlantycki i stopniowo tracili zainteresowanie wzmacnianiem mechanizmów OBWE stanowiących instrumenty bezpieczeństwa „miękkiego”. Uważam to za niewłaściwe podejście, tym bardziej, że mocne, militarne gwarancje bezpieczeństwa już posiadamy, a nie dbając o pozostałe środki pozbawiamy siebie i całą OBWE możliwości oddziaływania tam, gdzie siła wojskowa jest niewłaściwa, nieskuteczna bądź niewystarczająca. Dzisiaj trwałe bezpieczeństwo państwa na arenie międzynarodowej można budować nie tylko na „twardych gwarancjach”. Potrzeba również uzupełniać je „miękkimi” zabezpieczeniami i widzieć rosnącą współzależność z bezpieczeństwem także tych państw, którym trudno było dotychczas zaufać. Świat się szybko zmienia, a wiele wskazuje na to, że państwa całej strefy OBWE stoją w obliczu takich samych lub podobnych wyzwań, a to może oznaczać, że ich przyszły los jest także zbieżny. Pytaniem zasadniczym dla naszych przywódców jest, czy potrafią tę zbieżność odczytać i dostosować do niej międzynarodową aranżację bezpieczeństwa, tak aby zbudować dodatkowy filar bezpieczeństwa, obejmujący całą strefę od Vancouver do Władywostoku.

OBWE jest unikatową instytucją, która jest w stanie odegrać konstruktywną rolę, zwłaszcza w sytuacjach trudnych, w których istnieje potrzeba prowadzenia szerokich negocjacji z udziałem wszystkich zainteresowanych stron. Wystarczy choćby wskazać, że Rosja i wiele innych państw poradzieckich pozostaje poza strukturami takimi jak NATO i UE. A przecież oczywistym jest, że Polska stoi przed największymi wyzwaniami w polityce wschodniej i nigdy nie osiągnie optymalnego bezpieczeństwa, gdy będzie mieć poczucie zagrożenia z tamtego kierunku. 


\section{Nowe wyzwania i zagrożenia dla bezpieczeństwa europejskiego a OBWE}

Obecnie sytuacja międzynarodowa jest złożona, ale nie jest beznadziejna. Rzeczywiście Europa stoi przed kilkoma trudnymi problemami. Kryzys ukraiński przechodzi w fazę spowolnionej intensywności, choć spodziewać się można komplikacji wewnątrz tego państwa. Natomiast słabnie napięcie na linii Zachód-Rosja. Dużo złego stało się w związku z rywalizacją o Ukrainę, ale ani Rosja, ani USA nie wykazują woli kontynuowania polityki konfrontacyjnej. Tym bardziej nie jest tym zainteresowana UE, gdyż nie dysponuje instrumentami silnego wpływu na Rosję, ani nie jest w stanie wziąć na swoje barki utrzymania oligarchicznej gospodarki Ukrainy. Ukraińcy sami muszą znaleźć najlepsze dla siebie rozwiązania polityczne, zaś na płaszczyźnie międzynarodowej bez szerokiego porozumienia z udziałem Ukrainy, Rosji i Zachodu nie rozwiąże się tego kryzysu, który ma głębokie źródła wewnętrzne.

UE stoi przed poważnym wyzwaniem jako projekt integracyjny. Dostrzec tu można takie zagrożenia jak: problemy Grecji i całej strefy euro, renacjonalizacja polityki państw członkowskich, brytyjski zamiar opuszczenia Unii, nieumiejętność Unii radzenia sobie z rosnącą falą imigrantów z Afryki Północnej i Bliskiego Wschodu, zagrożenie terroryzmem.

Dla całego Zachodu wielkim problemem i zagrożeniem jest Państwo Islamskie (IS), w mniejszym stopniu jest to też problemem dla Rosji, narażonej od południa na wpływy fundamentalizmu islamskiego. To USA i ich niektórzy sojusznicy z Europy Zachodniej ponoszą główną odpowiedzialność na powstanie skrajnie niebezpiecznego terroryzmu na Bliskim Wschodzie $\mathrm{w}$ formie IS i innych organizacji terrorystycznych. Takie są niestety rezultaty prowadzenia nierozumnych interwencji militarnych w Iraku, Afganistanie, wspierania Arabskiej Wiosny. Dziś ten barbarzyński terroryzm rekrutuje swoich bojowników w Europie, a nawet w państwach poradzieckich, stając się wyzwaniem dla całej strefy euroatlantyckiej. Dotychczas powściągliwa Turcja włączyła się w lipcu 2015 r. do wojny z IS atakując terytorium zdestabilizowanej Syrii, a przy okazji walczących o niepodległość Kurdów, mających swoje bazy w północnym Iraku. Rada NATO w geście solidarności wspiera Turcję.

To wszystko nie stabilizuje sytuacji, a wręcz przeciwnie wymyka się ona spod kontroli. Być może, że państwa zachodnie - wykorzystując zawarte z Iranem (w lipcu 2015 r.) porozumienie o pokojowym wykorzystaniu energii jądrowej - zdołają się dogadać z Teheranem w sprawie zwalczania terroryzmu.

Należy przypuszczać, że komplikowanie się sytuacji na Bliskim Wschodzie będzie nadal postępować. Nie wiemy dzisiaj, jak będzie się rozwijać sytuacja w Afganistanie, po przegranej tam przez USA i NATO kilkunastoletniej wojnie. To powinno skłaniać polityków zachodnich do poszerzania koalicji na rzecz zwalczania terroryzmu i ekstremizmu. Takim oczywistym koalicjantem jawi się Rosja. Tym bardziej, że Amerykanie i ich sojusznicy z Europy Zachodniej są zainteresowani udziałem w zagospodarowaniu zasobów kopalin znajdujących się pod dnem Morza Arktycznego. Rosja w tej rywalizacji przoduje, a interes fïm zachodnich powinien skłaniać ich państwa do współpracy z Rosja, a nie do rywalizacji. Wreszcie wielkim wyzwaniem dla Zachodu są wschodzące nowe mocarstwa takie jak Chiny czy Indie.

Powstaje zatem pytanie, jak umacniać dziś bezpieczeństwo międzynarodowe? 
Można je budować nie tylko na „twardych” gwarancjach. Potrzeba także uzupełniać je „miękkimi” zabezpieczeniami i widzieć rosnącą współzależność z bezpieczeństwem także tych państw, którym trudno było dotychczas zaufać. Takie bezpieczeństwo trzeba uzupełniać, a więc utrwalać siecią wielosektorowej współpracy w innych dziedzinach. Świat się szybko zmienia, a wiele wskazuje, że państwa całej strefy OBWE stoją w obliczu takich samych lub podobnych wyzwan, a to może oznaczać, że ich przyszły los jest także zbieżny.

Pytaniem zasadniczym dla naszych polityków jest, czy potrafią tę zbieżność odczytać i dostosować do niej międzynarodową aranżację bezpieczeństwa tak, aby zbudować dodatkowy filar bezpieczeństwa obejmujący całą strefę od Vancouver do Władywostoku?

Uwzględniając te okoliczności można wskazać na naturalną potrzebę rewitalizacji współpracy w różnych dziedzinach na forum OBWE. W tej szerokiej organizacji międzynarodowej znajdują się państwa, które nie tylko rywalizują ze sobą - jak chociażby o Ukrainę - ale także mają wspólne interesy w umacnianiu bezpieczeństwa, choćby poprzez wspólne zwalczanie terroryzmu, budowanie zaufania międzynarodowego i rozwijania współpracy w innych dziedzinach. Taki scenariusz rozwoju sytuacji międzynarodowej dałby szansę na stworzenie wspomnianej wyżej, a werbalnie wspartej przez Polskę, idei stworzenia euroatlantyckiej i euroazjatyckiej wspólnoty bezpieczeństwa. A warto przywołać pogląd Karla Deutscha z 1957 r. o tym, że najpełniej zapewnić bezpieczeństwo można budując wspólnotę bezpieczeństwa.

\section{Bibliografia}

Bierzanek R. (1980), Wspólczesne stosunki międzynarodowe, Państwowy Instytut Wydawniczy. Warszawa.

Bromke A. (1983), Poland. The Protracted Crisis, Mosaic Press, Oakville (Ontario).

Charter for European Security (1999), Organization for Security and Co-operation in Europe, Vienna.

Ghebali V.-I. (1989), La diplomatie de la détente: la CSCE d'Helsinki à Vienne (1973-1989), Éditions Émile Bruylant, Bruxelles.

Giscard d'Estaing V. (1995), Le commencement de tout, „Politique internationale”, nr 68, s. 43-48.

Grudziński P., Pietrusiewicz J. (2001), Building a Modern Security Community in the Area from Vancouver to Vladivostok, „Bezpieczeństwo Narodowe”, nr 19, s. 51-62.

Heraclides A. (1993), Security and Co-operation in Europe: The Human Dimension, 1972-1992, Frank Cass, London.

Kozyriev A. (1994), The Lagging Partnership, „Foreign Affairs”, vol. 73, nr 3, s. 51-79.

Kupchan Ch. A. (2010), How Enemies Become Friends: the Sources of Stable Peace, Princeton University Press, Princeton-Oxford.

Lehne S. (1991), The Vienna Meeting of the Conference on Security and Cooperation in Europe, 1986-1989: A Turning Point in East-West Relations, Westview Press, Boulder CO.

Rachwald A. R. (1983), Poland between the Superpowers: Security vs. Economic Recovery, Westview Press, Boulder.

Rotfeld A. D. (1986), Europa między konfrontacja a wspólpraca. Spotkanie Madryckie KBWE: Doświadczenia i perspektywy, PISM, Warszawa. 
Zając J., Zięba R. (2005), Polska w stosunkach międzynarodowych 1945-1989, Wydawnictwo Adam Marszalek, Torun.

Zięba R. (2014), Międzynarodowe implikacje kryzysu ukrainskiego, „Stosunki Międzynarodowe - International Relations", t. 50, nr 2, s. 13-40.

Zięba R. (2004), Instytucjonalizacja bezpieczeństwa europejskiego: koncepcje-struktury - funkcjonowanie, wyd. IV, Wydawnictwo Naukowe Scholar, Warszawa.

Zięba R. (2013), Polityka zagraniczna Polski w strefie euroatlantyckiej, Wydawnictwa Uniwersytetu Warszawskiego, Warszawa.

\section{Streszczenie}

Podpisany w Helsinkach w 1975 roku Akt Końcowy KBWE otworzył nowy rozdział w poszukiwaniu optymalnego systemu bezpieczeństwa w strefie euroatlantyckiej, obejmującej obszar od Vancouver do Władywostoku. Ustanowił kooperatywny system bezpieczeństwa wprowadzający ponad blokowy mechanizm uzgadniania współpracy politycznej, gospodarczej i w dziedzinach humanitarnych, takich jak kultura, oświata, wymiana informacji i kontakty międzyludzkie. Po zimnej wojnie stworzono organy KBWE, wyposażono ją w nowe kompetencje w zakresie dyplomacji prewencyjnej i rozwiązywania konfliktów, ale ewolucja ładu międzynarodowego w Europie sprawiła, że wbrew początkowym zamierzeniem KBWE, przemianowana z początkiem 1995 roku na OBWE, nie stała się centralną instytucją bezpieczeństwa europejskiego. W wyniku rozszerzenia NATO i Unii Europejskiej na Wschód dokonało się odejście od zasady równego bezpieczeństwa dla wszystkich państw uczestniczących. OBWE pozostała drugorzędną instytucją wyspecjalizowaną w tzw. miękkich aspektach bezpieczeństwa. Kryzys ukraiński, wybuchły jesienią 2013 r., jak inne wyzwania i zagrożenia dla bezpieczeństwa pochodzące $z$ innych regionów ukazały potrzebę rewitalizacji OBWE i stworzenia euroatlantyckiej i euroazjatyckiej wspólnoty bezpieczeństwa.

Słowa kluczowe: Europejskie bezpieczeństwo, KBWE, OBWE, współpraca międzynarodowa

\section{European security forty years after the signing of the CSCE Final Act}

\section{Summary}

The CSCE Final Act, signed in Helsinki in 1975, opened a new chapter in the search for the optimal security system in the Euro-Atlantic area, stretching from Vancouver to Vladivostok. It established a cooperative security system introducing a supra-bloc negotiation mechanism of political and economic cooperation, as well cooperation in such humanitarian fields as culture, education, exchange of information and interpersonal contacts. After the Cold War, CSCE organs were created and equipped with new competences in the field of preventive diplomacy and conflict resolution, but the evolution of the international order in Europe meant that, contrary to the original intention of the CSCE (renamed at the beginning of 1995 as the OSCE), it has not become the central institution of European security. As a result of the Eastern enlargement of NATO and the European Union, the principle of equal security for all participating states was abandoned. The OSCE remained a secondary institution specialising in what is called the soft as- 
pects of security. The Ukrainian crisis, which broke out in the autumn of 2013, accompanied by other challenges and threats to security originating in other regions showed the need to revitalise the OSCE and create a Euro-Atlantic and Eurasian security community.

Key words: European security, CSCE, OSCE, international cooperation 